\title{
Conversion of Waste Cooking Oil to Biodiesel Catalysed by ZnAl Layered Double Hydroxide
}

\author{
Syahirah Shazwani, S, Noraini, H and Nazrizawati, A.T \\ Department of Chemistry and Environment, Faculty of Applied Sciences, Universiti Teknologi MARA,40450 Shah Alam, \\ Selangor
}

\begin{abstract}
In this study, the catalyst $\mathrm{ZnAl}$ layered double hydroxides (LDH) were successfully being synthesi sed with molar ratios 4:1 and 3:1 via free-alkali method by using ammonia solution instead of sodium hydroxide. The catalyst has been characterised before and after calcination by using XRD, TGA, SEM, BET and FT-IR. Based on the XRD result, the crystalline peak was successfully obtained and collapsed into mixed oxides of zinc oxide after the calcination. The carbonate decomposition was analysed by TGA to confirm the decomposition temperature of carbonate anions which is $250{ }^{\circ} \mathrm{C}$. The surface area performed by BET showing an increasing from $213 \mathrm{~m}^{2} / \mathrm{g}$ to $224 \mathrm{~m}^{2} / \mathrm{g}$ on ZnAl LDH. Carbonate anions were confirmed by FT-IR result which are at $1390 \mathrm{~cm}^{-1}$ and $856 \mathrm{~cm}^{-1} .1 \mathrm{wt} \%$ of calcined $\mathrm{ZnAl} \mathrm{LDH}$ catalyst has been used in the transesterification reaction using waste cooking oil (WCO). The compositions of biodiesel that has been detected using GC-FID are laurate, myristate, palmitate, linoleate, and stearate.
\end{abstract}

Keywords: alkali-free; $\mathrm{ZnAl}$ layered double hydroxide; waste cooking oil; transesterification

\section{INTRODUCTION}

An alternative fuel is very essential in today's industrial scenario due to the concern towards environmental health and safety. In the new global economy, fuel oil has become the central issue for steep market prices. Unfortunately, the fossil fuel keeps declined and predicted to be depleted soon (Aarøen et. al., 2021; Deng et al., 2020). This issue should require better alternative energy (Gaurav et al., 2016). The biodiesel production from vegetable oil is relatively easy and possess various environmental enhancements (Sahar et al., 2018). However, the major problem with this kind of oil is the high cost due to demand has increased massively (Keller et al., 2020).

The most ubiquitous technique used for production of biodiesel is transesterification reaction (Sahar et al., 2018). Biodiesel production by transesterification catalysed by homogeneous (acid and alkali) or heterogeneous catalyst (acid, alkali and enzyme) (Bukhtiyarova, 2019). Homogeneous catalysts can be base catalysts, such as sodium hydroxide $(\mathrm{NaOH})$ and potassium hydroxide $(\mathrm{KOH})$, or acid catalysts, such as sulphuric, sulphonic and phosphoric. Base catalysts reaction are preferable due to its higher catalytic activity and lower cost. However, base catalyst can react with free fatty acid (FFA) present in the feedstock during the transesterification which lead to the formation of soap by saponification. Therefore, the catalyst may be consumed and reduce its efficiency (Cao et al., 2016). Waste cooking oils (WCO) is one of the alternative ways to decrease biodiesel production cost (Gaurav et al., 2016).

Nevertheless, catalyst with alkali consumption can be difficult when the free fatty acid (FFA) content is high, despite the biodiesel yield and purity of the product is elevated (Bukhtiyarova, 2019). The challenge of high FFA content can be removed by esterification using sulphuric acid and methanol (Shan et al., 2018). In this process, heterogeneous catalysts that plays vital role to avoid saponification process occur and to prevent from massive from corroding the reactor. Consequently, heterogeneous catalysts such as metal oxides, mixed oxides, supported alkali metals, zeolites and hydrotalcites have been widely 
studied to replace homogeneous bases due to their less corrosion, easy separation and low environmental pollution.

Hydrotalcite is one of the heterogeneous catalysts, also known as layered double hydroxide (LDH) and belongs to a class of anionic clays (Figure 1). The general formula of hydrotalcite is $\left[\mathrm{M}(\mathrm{II})_{1-\mathrm{x}} \mathrm{M}(\mathrm{III})_{\mathrm{x}}(\mathrm{OH})_{2 \mathrm{x}+}\left(\mathrm{A}^{\mathrm{n}-\mathrm{x} / \mathrm{n}}\right) \cdot \mathrm{mH} 2 \mathrm{O}\right.$ (Bujok et al., 2020) (Liu et al., 2015), where MII and MIII resemble the divalent and trivalent metal cations (Elhalil et al., 2018). The formula $\mathrm{A}^{\mathrm{n}-}$ in the interlayer is indicated as the intercalation anions, which is to stable the excess positive charges (Liu et al., 2015). In the interlayer space, carbonate is located in it which to balance the anions charge (Liu et al., 2015). Divalent and trivalent cations can be used in their synthesis, e.g. $\mathrm{Zn}^{2+} / \mathrm{Al}^{3+}$, and $\mathrm{x}$, trivalent cation degree of substitution can take values in the range $0.2 \leqslant x \leqslant 0.33$ (Woodford et al., 2012). Co-precipitation is the most common technique used to prepare the hydrotalcite which involve the $\mathrm{pH}$ regulators. Recently, alkali-free method is introduced in the preparation of hydrotalcites to avoid alkalicontaminant and sodium entrain in the catalyst backbones (A.Tajuddin et. al., 2018; Tajuddin et al., 2019). In this method, ammonia and ammonium carbonate have been used instead of sodium hydroxide.

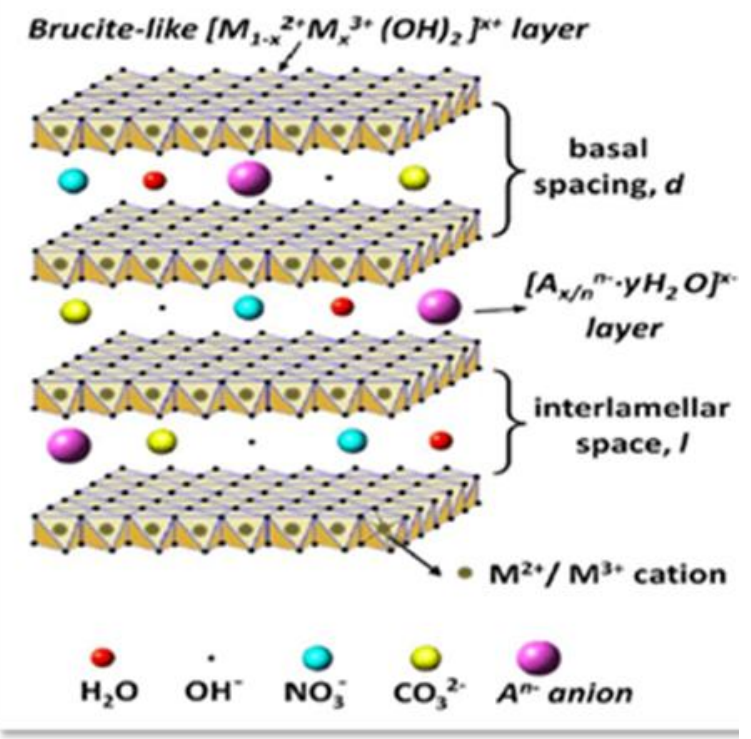

Figure 1. Cross-section of layered double hydroxide structure adapted from (Liu et al., 2015).

The LDHs structure can be improved through rehydration process known as "the memory effect" (Elhalil et al., 2018) when it is exposed to water as the hydroxide anions replace carbonate in the interlayer space. LDHs have many attractive properties such as flexibility, anion exchangeability and biocompatibility (Theiss et al., 2016). Among them, one of the most important properties for LDH is their excellent anion exchangeability. The aim of this study is to design an alkali-free heterogeneous catalyst mainly $\mathrm{Zn} \mathrm{Al}$ hydrotalcite and to be exposed in transesterification reaction of waste cooking oil.

\section{MATERIALS AND METHOD}

\section{A. Catalyst Synthesis}

LDHs was prepared with addition of mixed metal solutions of $29.75 \mathrm{~g}$ zinc nitrate $\left(\mathrm{Zn}\left(\mathrm{NO}_{3}\right)_{2} \cdot 6 \mathrm{H}_{2} \mathrm{O}\right)$ and $37.52 \mathrm{~g}$ of aluminium nitrate nonahydrate $\left(\mathrm{Al}\left(\mathrm{NO}_{3}\right)_{3} .9 \mathrm{H}_{2} \mathrm{O}\right)$ in $100 \mathrm{~mL}$ of volumetric flasks and was labelled as solution A (3:1 ratio) (Mahjoubi et al., 2017). 19.22 g of ammonium carbonate $\left(\mathrm{NH}_{4}\right)_{2} \mathrm{CO}_{3}$ was dissolved in $100 \mathrm{~mL}$ of distilled water. The $\mathrm{pH} 10$ was kept constant by the addition of $0.5 \mathrm{M}$ buffer ammonium carbonate $\left(\mathrm{NH}_{4}\right)_{2} \mathrm{CO}_{3}$. The final products were washed several times with distilled water and then dried for $5 \mathrm{~h}$ at $100{ }^{\circ} \mathrm{C}$. Parts of the synthesised products was calcined at $250{ }^{\circ} \mathrm{C}$ for $5 \mathrm{~h}$ and was cooled under a flowing stream of wet nitrogen (100 $\mathrm{ml} \mathrm{min} \mathrm{min}^{-1}$, relative humidity 95\%) before catalyst testing (Zhao et al., 2016). The similar steps has been taken to synthesise 4:1 Zn:All ratio except the weight of $\mathrm{Zn}$ and $\mathrm{Al}$ has been adjusted to fit this particular ratio.

\section{B. Catalyst Characterisation}

X-ray diffraction (XRD) was used to obtain information on crystalline structure on the catalyst. The XRD measurements were performed on Philips X'Pert Pro Super X-ray diffractometer equipped with and X'Celerator detection system and $\mathrm{CuK}$ alpha radiation ( $40 \mathrm{kV}$ and $30 \mathrm{~mA}$ ) was used as the X-ray source. Scans were performed over the $2^{\circ}$ range of $10^{\circ}-80^{\circ}$.

Thermal gravimetric analysis (TGA) was conducted on the as-synthesised catalyst to obtain the temperature of carbonate anions started to decompose. The temperature was raised from $25^{\circ} \mathrm{C}$ to $300^{\circ} \mathrm{C}$ with a heating rate of $10^{\circ} \mathrm{C}$ per minutes. TGA analysis was performed in an oxidative atmosphere (inert gas mixtures) with a linear temperature ramp. 
A scanning electron microscope (SEM) was conducted on the catalyst fresh and calcined catalyst to obtain the morphology of the catalyst. The SEM images were obtained from a JSM-670oF field emission (FE) microscope operating at $15 \mathrm{kv}$ which fitted with Energy Dispersive X-Ray Spectroscopy (EDX). Brunauer-Emmett-Teller (BET) analysis provide precise specific surface area of the $\mathrm{ZnAl}$ LDH catalyst by nitrogen multilayer adsorption measured as a function of relative pressure using a fully automated analyser. LDHs was degassed at $100{ }^{\circ} \mathrm{C}$ and $300{ }^{\circ} \mathrm{C}$ for $2 \mathrm{~h}$, respectively. The formation of channels and pores are due to water and carbonate anions removal during the calcination process which give the access of $\mathrm{N}_{2}$ molecules therefore, increase the surface area of the catalyst (Boukhalfa et al., 2017). The infrared spectra were obtained on Jasco FT-IR460 spectrometer in range of $4500-900 \mathrm{~cm}^{-1}$ using KBR pellet technique.

\section{Biodiesel Production}

\section{Pretreatment of waste cooking oil (WCO)}

Waste cooking oil was treated to get rid of the impurities such as free fatty acid (FFA) water (Abdul Raqeeb, 2015). Saponification can be formed when water is presence in the oil and a high FFA content (Gebremariam \& Marchetti, 2018). This will cause catalyst consumption and the production of biodiesel will be low (Abdul Raqeeb, 2015). The treatment of WCO was started with centrifuge then filtered to remove the cooked food. Next, determination of acid value by acid base titration and moisture content of the waste cooking oil were obtained.

To determine the free fatty acid (FFA) content, $1 \mathrm{~g}$ of oil was dissolved in $25 \mathrm{~mL}$ of ethanol and $25 \mathrm{~mL}$ of diethyl-ether with a few drops of phenolphthalein was added as indicator. The titration process was stopped when the solution turned into light pink colour. The acid value (AV) was calculated using the equation:

$$
\mathrm{AV}(\mathrm{mg} \mathrm{KOH} / \mathrm{g})=\frac{56.1 \times \mathrm{C}(\mathrm{KOH}) \times \mathrm{V}(\mathrm{KOH})}{\text { Mass of oil }}
$$

Where: 56.1 is the MW of the $\mathrm{KOH}$

$\mathrm{V}(\mathrm{KOH})$ is volume of $\mathrm{KOH}$ consume during titration

$\mathrm{C}(\mathrm{KOH})$ is the concentration of $\mathrm{KOH}$

\section{Transesterification Process}

$25 \mathrm{~g}$ of waste cooking oil was poured in a three-necked round bottom flask equipped with a reflux condenser and coolwater chiller. The waste cooking oil was heated at $100^{\circ} \mathrm{C}$ for 30 min to remove traces of water. Mixture of methanol to oil ratio used for this process was 15:1 with $5 \%$ base catalyst were added and reaction was ran at $65{ }^{\circ} \mathrm{C}$ at $24 \mathrm{~h}$. The reaction mixture was transferred into the separating funnel. The biodiesel from the upper layer was collected and the bottom layer of oil was discarded. The rotary evaporator was used to completely remove the glycerol leaving only biodiesel. The final product which is biodiesel was characterised by using Gas Chromatography (Agilent Technologies 6890N) equipped with Flame Ionisation Detector (FID) and 30m x $250 \mu \mathrm{m} \mathrm{HP} 5$-MS capillary column. The injection port was furnished with split mode (40:1) with $250{ }^{\circ} \mathrm{C}$ injection port temperature. The column temperature was initially set at $100{ }^{\circ} \mathrm{C}$ and increased until $290^{\circ} \mathrm{C}$ at $40^{\circ} \mathrm{C}$ $\mathrm{min}^{-1}$. The carrier gas flow was $30 \mathrm{ml} \mathrm{s}^{-1}$ and the detector temperature was fitted at $250{ }^{\circ} \mathrm{C}$.

\section{RESULT AND DISCUSSION}

\section{A. Catalyst Characterisation}

Thermal stability before calcination of the $\mathrm{ZnAl} \mathrm{LDH}$ catalyst was first investigated to the determine the right temperature of decomposition of $\mathrm{CO}_{3}{ }^{2-}$ on $\mathrm{LDH}$ sample. Figure 2 shows the TG-DTG curves obtained for the $\mathrm{ZnAl} \mathrm{LDH}$ of molar ratio 4:1 which indicating two main weight loss stages. The first transition associated with the loss of water (dehydration) that occurs around $100-150{ }^{\circ} \mathrm{C}$. Meanwhile, a second transition was observed around $250{ }^{\circ} \mathrm{C}$ corresponds with the decomposition of the carbonate anions and decarboxylation/dihydroxylation of the LDH sheets with mass loss $84.64 \%$. This temperature indicates the brucitelike layers start to collapse and $\mathrm{CO}_{3}{ }^{2-}$ interlayer decomposed to yield $\mathrm{CO}_{2}$. This temperature was used as a key indicator for a right calcination process. 


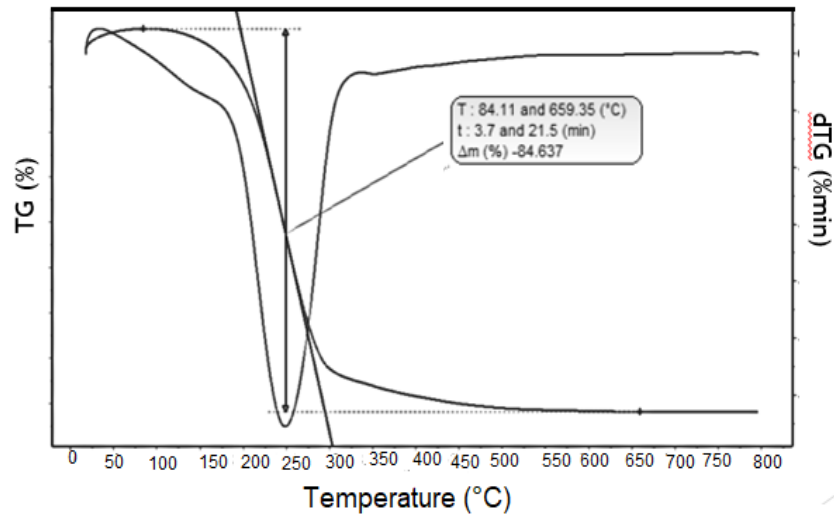

Figure 2. The TGA/dTG profiles during decomposition of

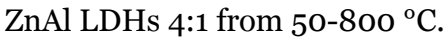

The XRD was successfully conducted on catalyst before and after calcinations. Based on the XRD patterns of assynthesised catalyst shown in Figure 3, the basal planes of (oo3), (006) and (oo9) peaks are at low $2 \theta$ angles meanwhile the basal plane of (101), (015), (0012) (110) and (113) planes are at high $2 \theta$ angles (Seftel et al., 2018). This shows that the catalyst are highly crystalline materials since the peaks are relatively sharp.
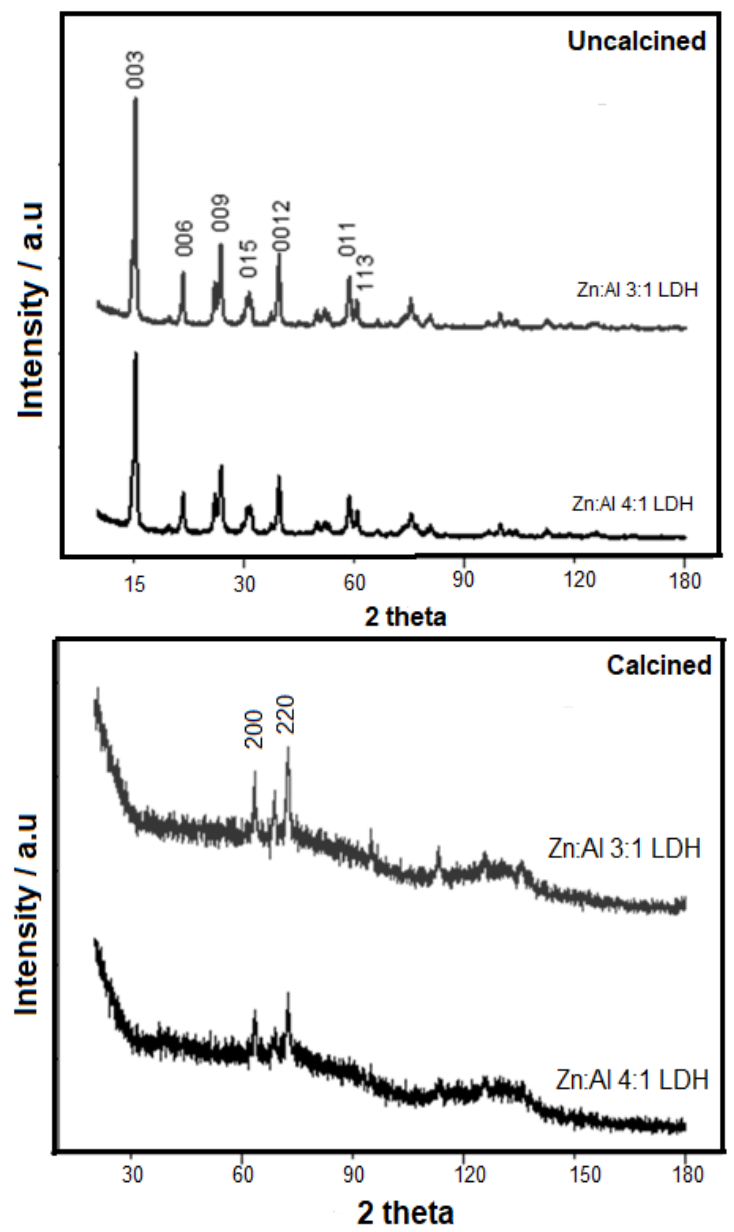

Figure 3. The XRD patterns of uncalcined and calcined $\mathrm{ZnAl}$ LDHs with ratio spanning from 3:1 to 4:1, respectively.
The unit cell parameters and the crystallite size for the $\mathrm{ZnAl}$ LDH were obtained, and the result are listed in Table 1 . The c parameter corresponds to three times the distance between adjacent brucite-like layers, and the parameter is almost the same as that of brucite for which $\mathrm{a}=3.10 \AA$. The basal spacing corresponds to $\mathrm{CO}_{3}{ }^{2-}$ containing LDHs. These values are in the literature range (Starukh et al., 2016). $\mathrm{ZnAl} \mathrm{LDH}$ was calcined in air at $250{ }^{\circ} \mathrm{C}$ for $4 \mathrm{~h}$ to obtain a mixture of zinc and aluminium oxides. The XRD patterns of calcined $\mathrm{ZnAl} \mathrm{LDH}$ shows formation of metal oxides $\mathrm{ZnO}$ and $\mathrm{ZnAl}_{3} \mathrm{O}_{4}$ corresponding to 200 and 220 reflections (Boukhalfa et al., 2017).

Table 1. Structural parameters of $\mathrm{ZnAl} \mathrm{LDHs}$

\begin{tabular}{lc}
\hline Parameters & Value \\
\hline Lattice parameter $\mathrm{a}=2 \mathrm{~d}_{110}, \AA$ & 3.074 \\
Lattice parameter $\mathrm{c}=3 \mathrm{~d}_{\mathrm{oo} 3}, \AA$ & 22.8 \\
Basal spacing doo3, $\AA$ & 7.60 \\
Interlayer distance $a, \AA$ & 2.8 \\
Crystallite size, $\AA$ & 172 \\
\hline
\end{tabular}

The SEM images of the sample studied are presented in Figure 4 where it shown a structure with irregular edges (Seftel et al., 2018). The calcined $\mathrm{ZnAl} \mathrm{LDH} \mathrm{sample} \mathrm{retains}$ platelet shape with exhibited the characteristic hexagonal plate-like of anionic clays. This further demonstrated that amorphous formation of HTs was succefully gained after calcination as proven and aligned with XRD results.

The surface area of $\mathrm{ZnAl} \mathrm{LDH}$ catalysts were investigated by using the $\mathrm{N}_{2}$ adsorption/desorption technique. Figure 5 shows the $\mathrm{N}_{2}$ sorption isotherms of uncalcined and calcined Zn:Al 4:1 LDH. The isotherms represent type IV hysterisis with resembles the mesoporous absorbent and pore wider more than $4 \mathrm{~nm}$. The specific surface area of calcined $\mathrm{ZnAl}$ $\mathrm{LDH}$ of molar ratio 3:1 and 4:1 increased from $213 \mathrm{~m}^{2} / \mathrm{g}$ to $224 \mathrm{~m}^{2} / \mathrm{g}$, respectively. 

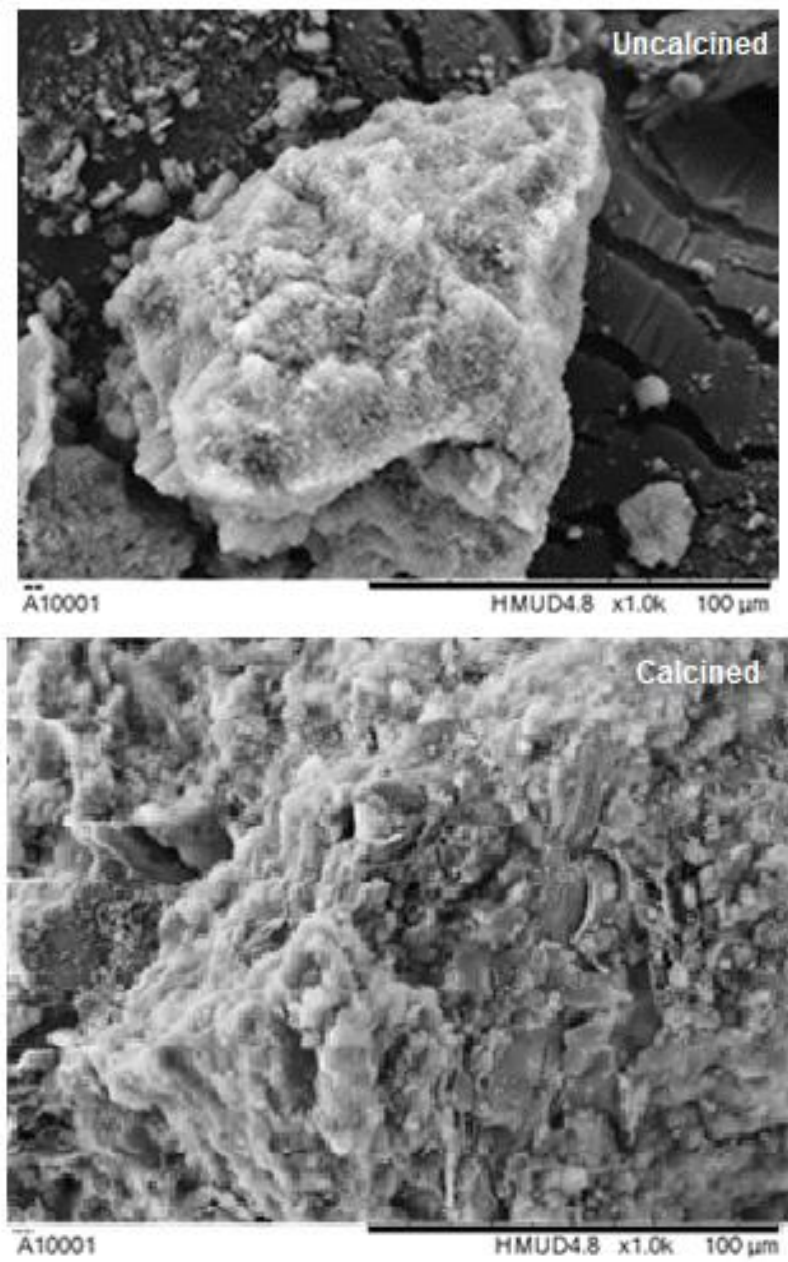

Figure 4. SEM images of $\mathrm{Zn}: \mathrm{Al}$ 4:1 LDH of uncalcined and calcined at $100 \mu \mathrm{m}$ magnification.

The formation of channels and pores are due to water and carbonate anions removal during the calcination process which give the access of $\mathrm{N}_{2}$ molecules therefore, increase the area of the catalyst (Boukhalfa et al., 2017). The presence of carbonate anions in LDH structure can be proved by FT-IR spectroscopy. The IR spectra of the uncalcined ZnAl LDH and its calcined forms are presented at Figure 6. For both spectrums, the broad absorption around $3456 \mathrm{~cm}^{-1}$ and 3467 $\mathrm{cm}^{-1}$ are assigned to $\mathrm{O}-\mathrm{H}$ stretching of water molecules in the brucite-like layers (Zhang et al., 2013). The stretching and bending modes of $\mathrm{CO}_{3}{ }^{2-}$ are observed at $1390 \mathrm{~cm}-1$ and 856 $\mathrm{cm}^{-1}$ for unclacined LDH. In additions, the peak at $990 \mathrm{~cm}^{-1}$ and $639 \mathrm{~cm}^{-1}$ can be assigned to the interaction of $\mathrm{CO}_{3}{ }^{2-}$ with the brucite-like layers (Starukh et al., 2016). In the case of calcined LDHs, the bands at $1384 \mathrm{~cm}^{-1}$ are due to residue bulk polydentate carbonates. Thus, the crystal-layered structure is destroyed after calcination of LDHs as was confirmed with the XRD patterns as shown in Figure 2.
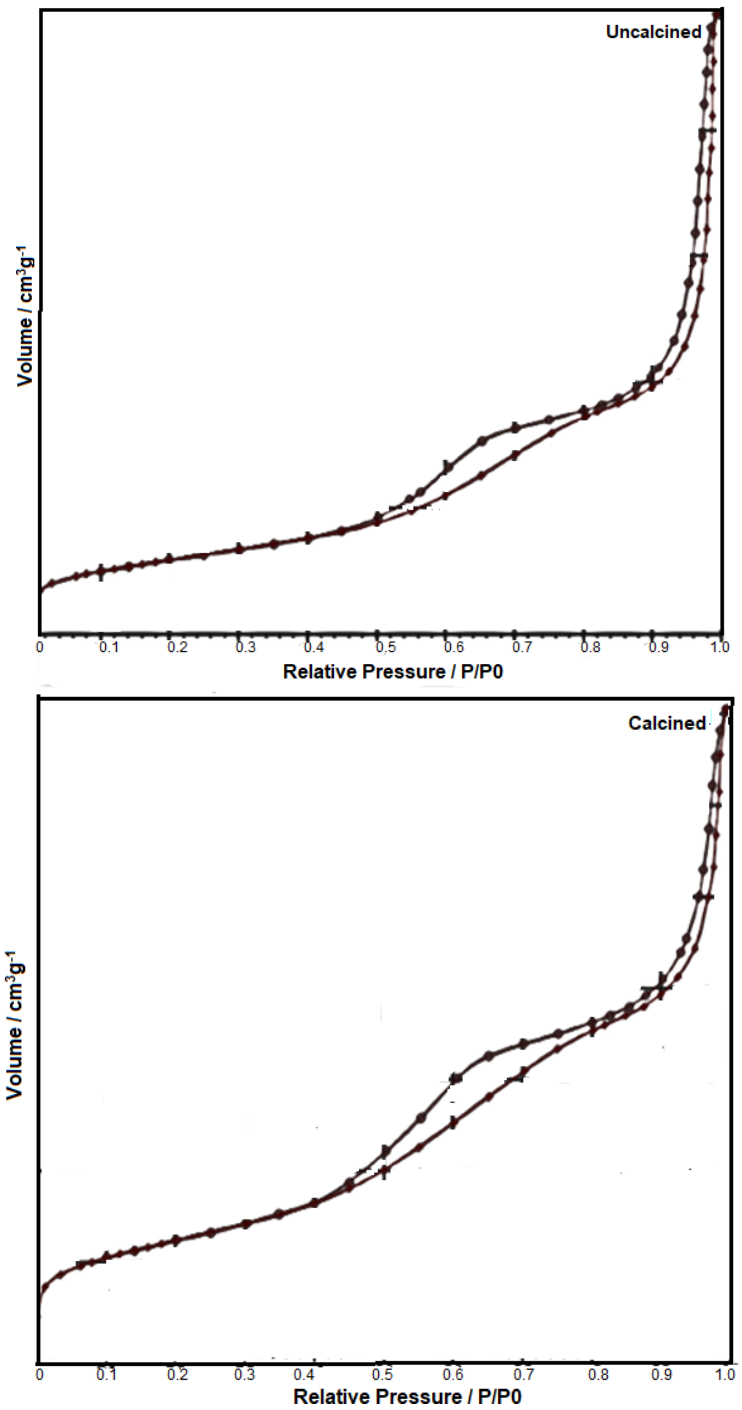

Figure 5. N2 adsorption/desorption of isotherm linear plot of uncalcined and calcined $\mathrm{ZnAl}$ 4:1 LDH

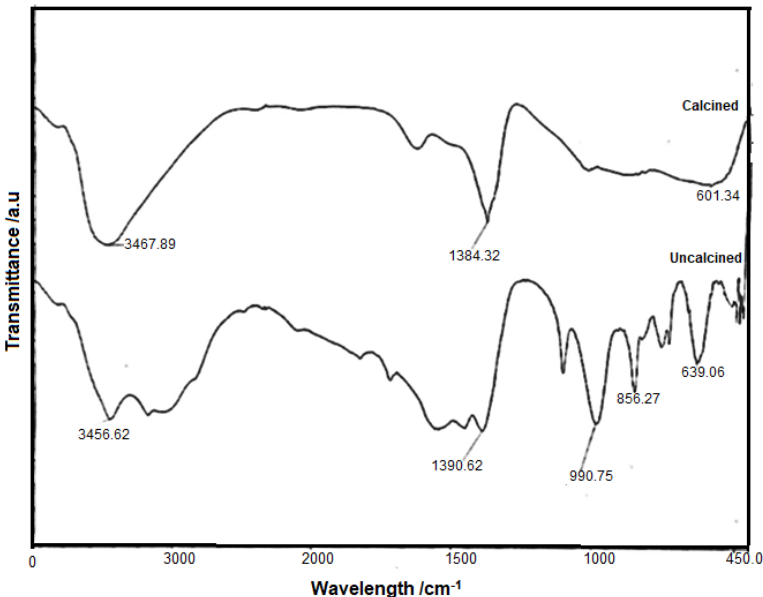

Figure 6. FTIR spectra of calcined and uncalcined Zn:Al 4:1 $\mathrm{LDH}$ 


\section{B. Biodiesel Production}

The transesterification reaction was done by using the calcined $\mathrm{ZnAl} \mathrm{LDH}$ which react as solid base heterogeneous catalyst. Prior to that, the acid value of the WCO was determined in order to obtain the acid content present in the WCO. The acid value, fatty acid and water content of waste cooking oil sample obtained in acid-base titration was tabulated in Table 2. It shows that the acid value and FFA of untreated WCO obtained were lower than previous study done by Sahar et al. (2018) which is $0.9665 \mathrm{mg} \mathrm{KOH} / \mathrm{g} \mathrm{WCO}$ and $0.39 \%$ WCO respectively. Therefore, there is no requirement for the two step reaction processes (esterification and transesterification) to be done here, hence can proceed to biodiesel production under tranesterification only.

Table 2. Acid, FFA value and moisture content for untreated waste cooking oil sample

\begin{tabular}{lc}
\hline Parameters & Value \\
\hline Acid value & $0.967(\mathrm{mg} \mathrm{KOH} / \mathrm{g}$ \\
& WCO $)$ \\
Fatty acid value & $0.39 \%$ \\
Water content & $0.64 \%$ \\
\hline
\end{tabular}

Characterisation of methyl ester compounds in biodiesel samples was analysed using GC-FID. In this study, the standard methyl esters used are methyl palmitate, methyl myristate, methyl stearate and methyl linoleate. Each of the single standard was injected to obtain persistent retention time reading and the result was tabulated in Table 3 . The biodiesel was produced by the reaction of 30:1 methanol/oil with 5 wt\% of calcined $\mathrm{ZnAl}$ hydrotalcite in the transesterification process. The yield of biodiesel for $3: 1$ and 4:1 $\mathrm{Zn}: \mathrm{Al}$ ratio were $28.5 \%$, and $32.7 \%$, respectively.

Table 3. Retention time of single standard FAME

\begin{tabular}{lc}
\hline FAME standard & Retention time \\
\hline Methyl myristate & 2.132 \\
Methyl palmitate & 2.950 \\
Internal standard (methyl hepta) & 3.558 \\
Methyl linoleate & 4.094 \\
Methyl stearate & 4.355 \\
\hline
\end{tabular}

\section{CONCLUSION}

In conclusion, $\mathrm{ZnAl} \mathrm{LDH} \mathrm{catalyst} \mathrm{with} \mathrm{molar} \mathrm{ratios} \mathrm{4:1} \mathrm{and}$ 3:1 have been successfully synthesised via alkali-free method and have been characterised by TGA, XRD, SEM, BET and FT-IR. Based on the TGA decomposition temperature, samples were calcined at $250{ }^{\circ} \mathrm{C}$. In XRD result, it was proved that the uncalcined LDH catalyst consist of crystalline materials since the peaks are relatively sharp and after the calcination, the LDH layer was successfully destroyed and converted to an amorphous material of mixed zinc aluminium oxides since the carbonate anions have been removed. This was further confirmed by SEM images where the crystalline and amorphous structures are clearly seen in uncalcined and calcined samples, respectively.

Meanwhile the surface area of the calcined $\mathrm{ZnAl} \mathrm{LDH}$ is increasing from $212.9406 \mathrm{~m} 2 / \mathrm{g}$ to $224.1770 \mathrm{~m} 2 / \mathrm{g}$, respectively which shows that the calcination give the access of N2 molecule to penetrate into the catalyst due to the removal of interlayer anion. The presence of carbonate anions can be proved from the FT-IR result which occurred at $1390 \mathrm{~cm}-1$ and $1384 \mathrm{~cm}-1$ is the residue bulk polydentate carbonate.

The production of biodiesel using waste cooking oil has been successfully conducted through transesterification reaction since the value of acid value obtained is $0.967 \mathrm{mg}$ $\mathrm{KOH} / \mathrm{g}$ and further analysed by using GC-FID analysis. The yield of biodiesel for 3:1 and 4:1 $\mathrm{Zn}: \mathrm{Al}$ calcined ratio were $28.5 \%$, and $32.7 \%$, respectively.

As for the recommendation, biodiesel properties should be further study to ensure that the quality meets European Standard of biodiesel (EN4214). Last but not least, the basicity of the catalyst $\mathrm{ZnAl} \mathrm{LDH}$ should be further investigated to determine the active basic-site of the catalyst itself and compare it with the surface area of the catalyst.

\section{ACKNOWLEDGEMENT}

The authors would like to thank the Research Management Centre (RMC), and Universiti Teknologi MARA (UiTM) to finance the project under GPK grant (6oo-RMC/GPK 5/3 (117/2020)). 


\section{REFERENCES}

A Tajuddin, N, Manayil, JC, Isaacs, MA, Parlett, CMA, Lee, $\mathrm{AF}$ \& Wilson, $\mathrm{K}$ 2018, 'Alkali-free $\mathrm{Zn}-\mathrm{Al}$ layered double hydroxide catalysts for triglyceride transesterification', Catalysts, vol. 8, pp. 1-11.

Aarøen, O, Riccardi, E \& Sletmoen, M 2021, 'Exploring the effects of approach velocity on depletion force and coalescence in oil-in-water emulsions', RSC Adv., vol. 11, pp. 8730-8740.

Abdul Raqeeb, M \& BR 2015, 'Biodiesel production from waste cooking oil', Available online www.jocpr.com J. Chem. Pharm. Res., vol. 7, pp. 670-681.

Boukhalfa, N, Boutahala, M, \& Djebri, N 2017, 'Synthesis and characterization of ZnAl-layered double hydroxide and organo-K10 montmorillonite for the removal of diclofenac from aqueous solution', Adsorpt. Sci. Technol., vol. 35, pp. 20-36.

Bujok, S, Konefał, M, Abbrent, S, Pavlova, E, Svoboda, J, Trhlíková, O, Walterová, Z \& Beneš, H 2020, 'Ionic liquidfunctionalized LDH as catalytic-initiating nanoparticles for microwave-activated ring opening polymerization of $\epsilon$ caprolactone', React. Chem. Eng., vol. 5, pp. 506-518.

Bukhtiyarova, MV 2019, 'A review on effect of synthesis conditions on the formation of layered double hydroxides', J. Solid State Chem., vol. 269, pp. 494-506.

Cao, Y, Li, G \& Li, X 2016, 'Graphene/layered double hydroxide nanocomposite: Properties, synthesis, and applications', Chem. Eng. J.

Deng, Z, Jiang, Y, Chen, K, Gao, F \& Liu, X 2020, 'Petroleum Depletion Property and Microbial Community Shift After Bioremediation Using Bacillus halotolerans T-04 and Bacillus cereus 1-1', Front. Microbiol. vol. 11, pp. 353.

Elhalil, A, Farnane, M, Machrouhi, A, Mahjoubi, FZ, Elmoubarki, R, Tounsadi, H, Abdennouri, M \& Barka, N 2018, 'Effects of molar ratio and calcination temperature on the adsorption performance of $\mathrm{Zn} / \mathrm{Al}$ layered double hydroxide nanoparticles in the removal of pharmaceutical pollutants', J. Sci. Adv. Mater. Devices, vol. 3, pp. 188-195. Gaurav, A, Ng, FTT \& Rempel, GL 2016, 'A new green process for biodiesel production from waste oils via catalytic distillation using a solid acid catalyst - Modeling, economic and environmental analysis', Green Energy Environ, vol. 1, pp. 62-74.

Gebremariam, SN \& Marchetti, JM 2018, 'Economics of biodiesel production: Review', Energy Convers. Manag.
Keller, F, Lee, RP \& Meyer, B 2020, 'Life cycle assessment of global warming potential, resource depletion and acidification potential of fossil, renewable and secondary feedstock for olefin production in Germany', J. Clean. Prod., vol. 250, pp. 119484.

Liu, Y, Yang, Z, Xie, X, Huang, J \& Wen, X 2015, 'Layered Double Oxides Nano-flakes Derived From Layered Double Hydroxides: Preparation, Properties and Application in Zinc/Nickel Secondary Batteries', Electrochim. Acta 185, pp. 190-197.

Mahjoubi, FZ, Khalidi, A, Abdennouri, M \& Barka, N 2017, 'Zn-Al layered double hydroxides intercalated with carbonate, nitrate, chloride and sulphate ions: Synthesis, characterisation and dye removal properties', J. Taibah Univ. Sci. vol. 11, pp. 90-100.

Sahar, Sadaf, S, Iqbal, J, Ullah, I, Bhatti, HN, Nouren, S, Habib-ur-Rehman, Nisar, J \& Iqbal, M 2018, 'Biodiesel production from waste cooking oil: An efficient technique to convert waste into biodiesel', Sustain. Cities Soc.

Seftel, EM, Ciocarlan, RG, Michielsen, B, Meynen, V, Mullens, S \& Cool, P 2018, 'Insights into phosphate adsorption behavior on structurally modified $\mathrm{ZnAl}$ layered double hydroxides', Appl. Clay Sci, vol. 165, pp. 234-246.

Shan, R, Lu, L, Shi, Y, Yuan, H \& Shi, J 2018, 'Catalysts from renewable resources for biodiesel production', Energy Convers. Manag.

Starukh, G, Rozovik, O \& Oranska, O 2016, 'Organo/Zn-Al LDH Nanocomposites for Cationic Dye Removal from Aqueous Media', Nanoscale Res. Lett. vol. 11, pp. 228.

Tajuddin, NA, Saleh, R, Manayil, JC, Isaacs, M, Parlett, CMA, Lee, AF \& Wilson, K 2019, 'Hydrothermal reconstructing routes of alkali-free znal layered double hydroxide: A characterization study', in: Solid State Phenomena. Trans Tech Publications Ltd, pp. 168-176.

Theiss, FL, Ayoko, GA \& Frost, RL 2016, 'Synthesis of layered double hydroxides containing $\mathrm{Mg} 2+, \mathrm{Zn} 2+, \mathrm{Ca} 2+$ and $\mathrm{Al}$ 3+ layer cations by co-precipitation methods - A review', Appl. Surf. Sci., vol. 383, pp. 200-213.

Woodford, JJ, Dacquin, JP, Wilson, K \& Lee, AF 2012, 'Better by design: nanoengineered macroporous hydrotalcites for enhanced catalytic biodiesel production', Energy Environ. Sci., vol. 5, pp. 6145 .

Zhang, W, De, Zheng, YM, Xu, Y, Sen, Yu, YX, Shi, QS, Liu, L, Peng, H \& Ouyang, Y 2013, 'Preparation and 
antibacterial property of waterborne polyurethane/Zn-Al layered double hydroxides/ZnO nanocomposites', J. Nanosci. Nanotechnol., vol. 13, pp. 409-416.

Zhao, Y, Li, N, Xu, B, Dong, B \& Xia, S 2016, 'Preparation and characterization of a novel hydrophilic poly(vinylidene fluoride) filtration membrane incorporated with $\mathrm{Zn}-\mathrm{Al}$ layered double hydroxides', J. Ind. Eng. Chem., vol. 39, pp. $37-47$. 